\title{
Minimum plot size to evaluate potato tuber yield traits
}

\author{
Arione S Pereira ${ }^{1}$; Giovani O Silva ${ }^{2}$; Agnaldo DF Carvalho ${ }^{3}$

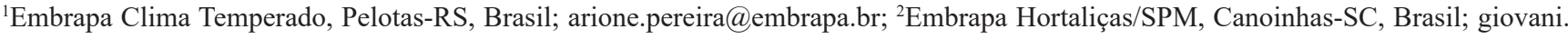 \\ olegario@embrapa.br; ${ }^{3}$ Embrapa Hortaliças, Brasília-DF, Brasil; agnaldo.carvalho@embrapa.br
}

\begin{abstract}
The proper plot size is essential to reduce experimental error and thereby maximize precision of data obtained in an experiment. The objective of this work was to estimate the minimum number of plants per plot to assess tuber yield traits of potato genotypes. Four advanced potato clones (F161-07-02, F189-06-09, F97-08-07 and F131-08-06) of the breeding program of Embrapa were evaluated. The experiment was conducted in the fall season of 2015, in Canoinhas, Santa Catarina State, Brazil. A randomized complete block design with two replications of 20-plant two-row plots was used. At 112 days after planting, plants of each plot were individually harvested and evaluated for tuber yield traits. The modified maximum curvature and the repeatability methods were used to estimate the minimum plant number to represent the genotypes in each plot. We found that 10 to 14 plants per plot are enough to guarantee an adequate precision and predict the real value of the individuals for tuber yield traits in experiments of two replications, considering an R2 of $90 \%$ for the repeatability method.
\end{abstract}

Keywords: Solanum tuberosum ssp. tuberosum, maximum modified curvature, repeatability.

\section{RESUMO}

Tamanho mínimo de parcela para avaliação de caracteres de rendimento em tubérculo em batata

O correto dimensionamento das parcelas experimentais é fundamental para reduzir o erro experimental e, com isso, maximizar a precisão das informações obtidas em um experimento. O objetivo do trabalho foi estimar o número mínimo de plantas por parcela para avaliação de genótipos de batata, para caracteres de rendimento de tubérculo. Foram avaliados quatro clones avançados de batata (F161-07-02, F189-06-09, F97-08-07 e F131-08-06), pertencentes ao programa de melhoramento genético da Embrapa. O experimento foi conduzido em Canoinhas-SC, no outono de 2015, utilizando o delineamento em blocos casualisados com duas repetições e parcelas com 20 plantas divididas em duas linhas. Aos 112 dias após o plantio as plantas de cada parcela foram colhidas individualmente e avaliadas para caracteres de rendimento de tubérculo. Os métodos da curvatura máxima modificado e repetibilidade foram utilizados para estimar o número mínimo de plantas para representar os genótipos em cada parcela. Pode-se verificar que na avaliação de clones de batata para caracteres de rendimento de tubérculos, a utilização de 10 a 14 plantas por parcela em ensaios com duas repetições é suficiente para garantir adequada precisão experimental e predizer o valor real dos indivíduos, considerando um R2 de 90\% no caso da metodologia baseada no coeficiente de repetibilidade.

Palavras-chave: Solanum tuberosum ssp. tuberosum, curvatura máxima modificado, repetibilidade.

Received on October 28, 2016; accepted on April 7, 2017

$\mathrm{T}$ he proper plot size is essential to reduce experimental error and thereby maximize precision of data obtained in an experiment (Schwertner et al., 2015).

In breeding programs, the reduction of experimental error can be achieved by optimizing the number of plants per plot and the number of replicates, which result in decrease of the phenotypic variance, contributing to the increase of the coefficient of heritability, and consequently to genetic progress with selection. Besides that, the plot size is directly linked to the cost of implementing experiments and evaluations, and the balance between cost and precision determines the optimal plot size (Storck et al., 2006; Vieira \& Silva, 2008).

The increase in plot size leads to a decrease in variation between plots. However, the decrease is not infinitely proportional to the size of the plot, since little gain in precision is obtained by increasing the size of experimental units already large enough. The minimum sample size in breeding trials depends on the species, the type of population under evaluation, the inferences to be made, the environmental conditions and the desired precision level (Alves \& Seraphin, 2004; Schwertner et al., 2015). In this way, it is important for breeding programs to carry out studies according to the local conditions in which selection is applied.

According to Silva et al. (2003), the method of maximum curvature of the coefficient of experimental variation (CV) function has been very consistent. According to Viana et al. (2002), the 
modified maximum curvature method provides more accurate results than the maximum curvature method, by establishing a regression equation to explain the relationship between coefficients of variation and respective plot sizes.

The potato is commercially propagated by seed tubers, which are modified stems for storage of starch reserves, i.e., a clone representing a given genotype are identical individuals. Based on this concept, the repeatability coefficient can be determined, and calculated when the measurement of a given trait is made repeatedly in the same individual in time or space. High repeatability estimates of a given trait indicate that it is feasible to predict the real value of the individual using a relatively small number of measurements, or that there is no variation in the expression of the trait in the successive evaluations, and the reverse occurring when the repeatability estimate is low (Cruz et al., 2012). The repeatability coefficient can be used to determine the number of measurements needed in individuals for predicting their real value, with a certain degree of probability (R2), which represents the percentage of certainty in predicting the real value of the selected individuals based on " $n$ " measurements (Costa, 2003).

The objective of this work was to estimate the minimum number of plants per plot to assess tuber yield traits of potato genotypes, using the maximum curvature and the repeatability methods.

\section{MATERIAL AND METHODS}

The experiment was conducted in Canoinhas, Santa Catarina State, Brazil (26 ${ }^{\circ} 10^{\prime} 38^{\prime \prime} \mathrm{S}, 50^{\circ} 23^{\prime} 24^{\prime \prime} \mathrm{W}$, altitude 839 $\mathrm{m})$. Four advanced potato clones (F16107-02, F189-06-09, F97-08-07, and F131-08-06) of the breeding program of Embrapa were grown in the fall season of 2015. A randomized complete block design with two replications of 20-plant two-row plots was used. Plants were spaced $0.40 \mathrm{~m}$ within row and $0.75 \mathrm{~m}$ between rows. The seeds were type II (diameter between 40 and $50 \mathrm{~mm}$ ), of the second field generation, stored for seven months in a cold room at temperatures of $4.0 \pm 0.5^{\circ} \mathrm{C}$. As fertilizer the commercial formula $04-14-08$ of N-P-K was used, at a dosage of $3.0 \mathrm{t} / \mathrm{ha}$. Cultural and phytosanitary treatments followed the recommendations of the region (Pereira, 2010). At 112 days after planting, plants of each plot were harvested and evaluated individually for the following yield trait components: number of commercial tubers (diameter over 45 $\mathrm{mm}$ ) per plant; mass of commercial tubers, in $\mathrm{g} / \mathrm{plant}$; total number of tubers per plant; total mass of tubers, in $\mathrm{g} /$ plant; and average mass of tubers, in $\mathrm{g} / \mathrm{plant}$, obtained by dividing total mass of tubers and total number of tubers.

The analysis of the minimum number of plants per plot to maximize the experimental precision, using the modified maximum curvature method was performed, considering the relationship between the number of individuals per plot and the coefficient of variation.

The determination of the coefficients of variation was performed by simulation of subsamples. The calculation was started with subsamples of two plants, and increment of one plant, from one round to the other. The number of plants was successively increased until reaching the total of 20 plants that composed the plot. For each sample size, there were 20 random sampling rounds with replacement. For each subsample, coefficients of variation were estimated, obtaining the average of the 20 subsamples of the same size.

The repeatability was estimated by the principal component analysis methodologies obtained from the correlation matrix and the matrix of phenotypic variances and covariates (Cruz \& Regazzi, 2001).

The necessary number of measurements to be performed on clones according to determination coefficient values, by repeatability analysis was also estimated. The repeatability was estimated by the analysis of the main component method, obtained from the correlation matrix and the phenotypic variance and covariance matrices (Cruz \& Regazzi, 2001).
All analyses were performed using the computational applicative Genes (Cruz, 2013). For the determination of the minimum number of plants, by the modified maximum curvature method, the expression presented by Chaves (1985) apud Vieira \& Silva (2008) was used:

$\mathrm{N}=[\mathrm{a} 2 \mathrm{~b} 2(2 \mathrm{~b}-1) /(\mathrm{b}-2)] 1 /(2-2 \mathrm{~b})$,

where "a" is the regression constant and "b" is the regression coefficient estimated from the adjustment of the model presented by Chaves (1985) apud Vieira \& Silva (2008), considering the coefficient of variation and the number of plants per plot.

\section{RESULTS AND DISCUSSION}

The highest experimental precision with the lowest initial number of plants was observed for total number of tubers and average mass of tubers (Figure 1). However, the increase in precision according to the increase in the number of plants was higher for mass of commercial tubers and total mass of tubers.

Despite average mass of tubers having one of the lowest values of the coefficient of variation, the increase in the number of plants per plot provided smaller increase in experimental precision as compared to other traits. It indicates that for this trait a smaller number of plants per plot would be necessary, unlike for the traits that measure the mass of the tubers.

The yield of potato tubers is a quantitative trait, which usually have great environmental influence (Silva et al., 2006). These authors observed CV values ranging from $17.31 \%$ to $21.03 \%$ for the yield, number, and average mass of potato tubers. Similar CV values were reported by Bisognin et al. (2008), varying between $16.19 \%$ and $25.60 \%$ for yield of tuber of different sizes of potato clones, and by Costa et al. (2007), values of $22.70 \%$ and $18.30 \%$ for total yield and total number of tubers of potato clones.

By the modified maximum curvature method (Figure 1), at least between 4.83 and 9.56 plants per plot are needed 


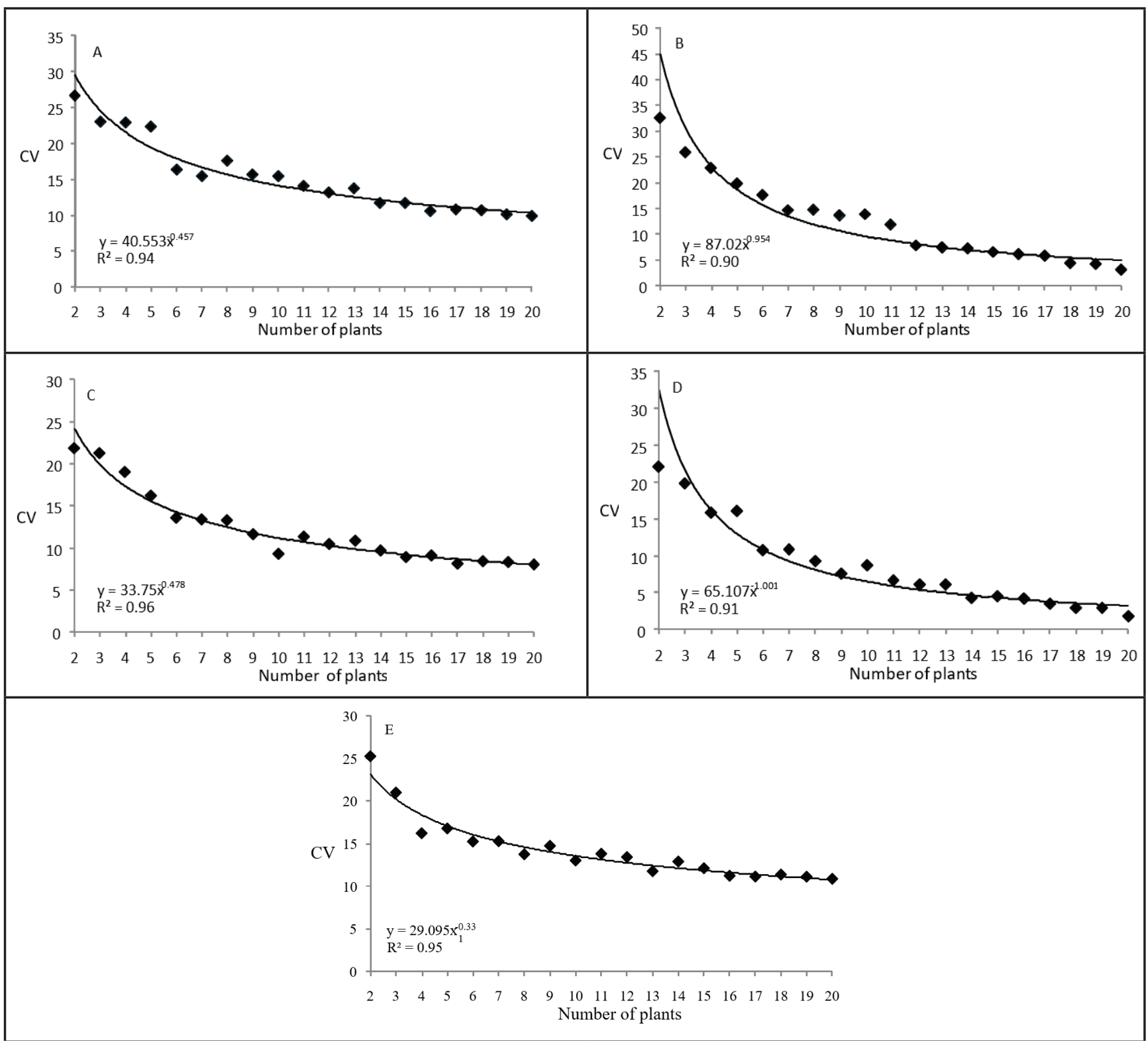

Figure 1. The minimum number of plants per plot for potato genotypes by the modified maximum curvature method for the traits: A) number of marketable tubers, 6.80 , B) mass of marketable tubers, 9.56, C) total number of tubers, 6.06, D) total mass of tubers, 8.06, and E) average mass of tubers, 4.83. CV: coefficient of experimental variation, in percentage. Canoinhas, Embrapa, 2015.

to obtain a better balance between experimental precision and experiment size for the evaluated potato yield traits.

The use of the regression equation allowed estimations of the minimum number of plants per plot in the intervals between the predetermined samples, in a non-subjective way and, in this case, with high precision, since the adjustments can be considered very good, with R2 values ranging from 0.90 to $0.95 \%$ for all traits.

According to Oliveira et al. (2006) and Vieira \& Silva (2008), in order to determine the ideal size of plots, it is important to use more than one methodology, due to the variation that may exist in the estimates of each one. For the coefficient of repeatability, we found that the number of measurements in the plots necessary to predict the true value of the genotypes with coefficient of determination (R2) of $90 \%$, in the mean of the replicates and the methodologies used, it ranged from 9.74 to 13.34 , and with R2 of $95 \%$ it ranged from 20.56 to 28.15 (Table 1).

These results of both estimation methods indicate that 10 to 14 plants per plot are sufficient to provide adequate experimental precision and to predict the real value of the individuals in experiments with potato clones. A higher number of plants would not add more information and would not provide significant reduction of error (Zanon \& Storck, 2000). This is considering an R2 of $90 \%$ by the repeatability coefficient, because if it were chosen by more or less precision the number of plants needed would be higher or lower, respectively. These values are about 30 to $50 \%$ lower 
Table 1. Estimates of number of plants per plot according to values of the coefficient of determination $\left(\mathrm{R}^{2}\right)$, the repeatability analysis, and by the methods of correlation and covariance of principal component, from the evaluation for tuber yield traits of four potato genotypes. Canoinhas, Embrapa, 2015.

\begin{tabular}{|c|c|c|c|c|c|}
\hline \multirow{2}{*}{$\mathbf{R}^{2}$} & \multicolumn{2}{|c|}{ Principal component correlation } & \multicolumn{2}{|c|}{ Principal component covariance } & \multirow{2}{*}{ Average value } \\
\hline & Replication 1 & Replication 2 & Replication 1 & Replication 2 & \\
\hline & \multicolumn{5}{|c|}{ Number of marketable tubers (tubers/plant) } \\
\hline 0.80 & 5.94 & 3.99 & 4.49 & 4.58 & 4.75 \\
\hline 0.85 & 8.41 & 5.66 & 6.36 & 6.48 & 6.73 \\
\hline 0.90 & 13.36 & 8.99 & 10.11 & 10.29 & 10.69 \\
\hline 0.95 & 28.20 & 18.97 & 21.33 & 21.74 & 22.56 \\
\hline \multirow[t]{2}{*}{0.99} & 146.94 & 98.92 & 111.17 & 113.27 & 117.58 \\
\hline & \multicolumn{5}{|c|}{ Mass of marketable tubers (g/plant) } \\
\hline 0.80 & 5.52 & 3.34 & 4.85 & 5.09 & 4.70 \\
\hline 0.85 & 7.82 & 4.73 & 6.87 & 7.21 & 6.66 \\
\hline 0.90 & 12.43 & 7.52 & 10.91 & 11.45 & 10.58 \\
\hline 0.95 & 26.23 & 15.87 & 23.03 & 24.17 & 22.33 \\
\hline \multirow[t]{2}{*}{0.99} & 136.68 & 82.71 & 120.02 & 125.94 & 116.34 \\
\hline & \multicolumn{5}{|c|}{ Total number of tubers (tubers/plant) } \\
\hline 0.80 & 6.38 & 3.50 & 6.47 & 7.35 & 5.93 \\
\hline 0.85 & 9.04 & 4.96 & 9.16 & 10.42 & 8.40 \\
\hline 0.90 & 14.36 & 7.88 & 14.55 & 16.55 & 13.34 \\
\hline 0.95 & 30.31 & 16.64 & 30.72 & 34.94 & 28.15 \\
\hline \multirow[t]{2}{*}{0.99} & 157.95 & 86.68 & 160.06 & 182.03 & 146.68 \\
\hline & \multicolumn{5}{|c|}{ Total mass of tubers (g/plant) } \\
\hline 0.80 & 3.15 & 3.54 & 4.85 & 5.78 & 4.33 \\
\hline 0.85 & 4.46 & 5.02 & 6.86 & 8.18 & 6.13 \\
\hline 0.90 & 7.08 & 7.97 & 10.90 & 13.00 & 9.74 \\
\hline 0.95 & 14.96 & 16.82 & 23.02 & 27.44 & 20.56 \\
\hline \multirow[t]{2}{*}{0.99} & 77.94 & 87.66 & 119.94 & 142.99 & 107.13 \\
\hline & \multicolumn{5}{|c|}{ Average mass of tubers (g/plant) } \\
\hline 0.80 & 2.94 & 4.37 & 6.11 & 5.59 & 4.75 \\
\hline 0.85 & 4.17 & 6.20 & 8.66 & 7.92 & 6.74 \\
\hline 0.90 & 6.62 & 9.84 & 13.75 & 12.58 & 10.70 \\
\hline 0.95 & 13.97 & 20.78 & 29.03 & 26.56 & 22.59 \\
\hline 0.99 & 72.80 & 108.30 & 151.26 & 138.41 & 117.69 \\
\hline
\end{tabular}

than the 20 of plants per plot used in the experiment of this study, indicating that in the evaluation of genotypes for these traits, a large experimental area can be saved, maintaining the same precision level. Also, the use of smaller plots makes it possible to evaluate more genotypes in the same area.

Storck et al. (2005) analyzed several experiment configurations and found that the optimal size of an experimental unit for potato is 24 plants, which is close to 20 to 30 plants reported by Oliveira \& Estefanel (1995), and is similar to the repeatability estimates with R2 of $95 \%$ found in this work. Storck et al. (2006), in a study aimed at estimating the relationship between area dimension with estimation of optimal plot size and experimental precision in potatoes, also found the need for a small number of plants per plot. The authors concluded that experiments with higher number of plants per row offer greater precision in the evaluation of tuber yield. And, plots with six plants in the row and the use of the row as a block also increases the precision of potato experiments.

The results of this work allow us to conclude that in the evaluation of potato clones for tuber yield traits, the use of 
10 to 14 plants per plot in two replicate trials is enough to guarantee adequate experimental precision and to predict the real value of the individuals, considering an R2 of $90 \%$ for the repeatability method.

\section{REFERENCES}

ALVES, SMF; SERAPHIN, JC. 2004. Coeficiente de heterogeneidade do solo e tamanho de parcela. Pesquisa Agropecuária Brasileira 39: 105-111.

BISOGNIN, DA; MÜLLER, DR; STRECK, NA; ANDRIOLO, JL; SAUSEN, D. 2008. Desenvolvimento e rendimento de clones de batata na primavera e no outono. Pesquisa Agropecuária Brasileira 43: 699-705.

COSTA, JG. 2003. Estimativas de repetibilidade de alguns caracteres de produção em Mangueira. Ciência Rural 33: 263-266.

COSTA, LC; BISOGNIN, DA; ANDRIOLO, JL; RITTER, CEL; BANDINELLI, MG. 2007. Identificação de clones de batata com potencial para mesa e adaptados para os cultivos de outono e primavera do Rio Grande do Sul. Ciência e Natura 29: 93-104.

CRUZ, CD; REGAZZI, AJ; Carneiro PCS.
2012. Modelos biométricos aplicados ao melhoramento genético. Viçosa: Editora UFV. $514 \mathrm{p}$.

CRUZ, CD. 2013. Genes - a software package for analysis in experimental statistics and quantitative genetics. Acta Scientiarum 35: 271-276.

CRUZ, CD; REGAZZI, AJ. 2001. Modelos biométricos aplicados ao melhoramento genético. Viçosa: Editora UFV. 390p.

OLIVEIRA, PH; ESTEFANEL, V. 1995. Tamanho e forma ótimos da parcela para avaliação do rendimento em experimentos com batata. Ciência Rural 25: 205-208.

OLIVEIRAS, JR; STORCK, L; LÚCIO, AD; LOPES, SJ; MARTINI, LFD. 2006. Índice de heterogeneidade, coeficiente de variação e tamanho ótimo de parcela em batata. Ciência Rural 36: 1710-1716.

PEREIRA, AS (org). 2010. Produção de batata no Rio Grande do Sul. Pelotas: Embrapa Clima Temperado. 95p (Sistema de Produção 19).

SILVA, RL; XAVIER, A; LEITE, HG; PIRES, IE. 2003. Determinação do tamanho ótimo da parcela experimental pelos métodos da máxima curvatura modificado, do coeficiente de correlação intraclasse e da análise visual em testes clonais de eucalipto. Revista Árvore 27: 669-676.

SILVA, GO; SOUZA, VQ; PEREIRA, AS;
CARVALHO, FIF; FRITSCHE-NETO, R. 2006. Early generation selection for tuber appearance affects potato yield components. Crop Breeding and Applied Biotechnology 6: 73-78.

STORCK, L; OLIVEIRA, SJR; GARCIA, DC; BISOGNIN, DA. 2005. Comprimento e largura do tamanho ótimo da plota experimental em batata. Ciência Rural 35: 1043-1048.

STORCK, L; BISOGNIN, DA; OLIVEIRA, SJR. 2006. Dimensões dos ensaios e estimativas do tamanho ótimo de parcela em batata. Pesquisa Agropecuária Brasileira 41: 903-909.

SCHWERTNER， DV； LÚCIO，AD; CARGNELUTTI FILHO, A. 2015. Size of uniformity trials for estimating the optimum plot size for vegetables. Horticultura Brasileira 33: 388-393.

VIANA, AES; SEDIYAMA, T; CECON, PR; LOPES, SC; SEDIYAMA, MAN. 2002. Estimativas de tamanho de parcela em experimentos com mandioca. Horticultura Brasileira 20: 58-63.

VIEIRA, JV; SILVA, GO. 2008. Tamanho mínimo de parcela para avaliação de caracteres de raiz em cenoura. Bragantia 67: 1047-1052.

ZANON, MLB; STORCK, L. 2000. Tamanho ótimo de parcelas experimentais para Eucalyptus saligna Smith. em dois estádios de desenvolvimento. Cerne 6: 104-111 